\title{
Focal Congenital Hyperinsulinism as a Cause for Sudden Infant Death
}

DOI:

$10.1177 / 1093526618765376$

\section{Document Version}

Accepted author manuscript

Link to publication record in Manchester Research Explorer

\section{Citation for published version (APA):}

Chinoy, A., Banerjee, I., Flanagan, S. E., Ellard, S., Han, B., Mohamed, Z., Dunne, M. J., \& Bitetti, S. (2018). Focal Congenital Hyperinsulinism as a Cause for Sudden Infant Death. Pediatric and Developmental Pathology. https://doi.org/10.1177/1093526618765376

\section{Published in:}

Pediatric and Developmental Pathology

\section{Citing this paper}

Please note that where the full-text provided on Manchester Research Explorer is the Author Accepted Manuscript or Proof version this may differ from the final Published version. If citing, it is advised that you check and use the publisher's definitive version.

\section{General rights}

Copyright and moral rights for the publications made accessible in the Research Explorer are retained by the authors and/or other copyright owners and it is a condition of accessing publications that users recognise and abide by the legal requirements associated with these rights.

\section{Takedown policy}

If you believe that this document breaches copyright please refer to the University of Manchester's Takedown Procedures [http://man.ac.uk/04Y6Bo] or contact uml.scholarlycommunications@manchester.ac.uk providing relevant details, so we can investigate your claim.

\section{OPEN ACCESS}




\section{Pediatric and Developmental Pathology}

\section{Focal Congenital Hyperinsulinism as a cause for Sudden Infant Death}

\begin{tabular}{|c|c|}
\hline Journal: & Pediatric and Developmental Pathology \\
\hline Manuscript ID & PDP-17-0084.R2 \\
\hline Manuscript Type: & Case Report \\
\hline Date Submitted by the Author: & 05-Dec-2017 \\
\hline Complete List of Authors: & $\begin{array}{l}\text { Chinoy, Amish; Royal Manchester Children's Hospital, Paediatric } \\
\text { Endocrinology } \\
\text { Banerjee, Indraneel; Royal Manchester Children's Hospital, Paediatric } \\
\text { Endocrinology } \\
\text { Flanagan, Sarah; University of Exeter Medical School, Institute of } \\
\text { Biomedical and Clinical Science } \\
\text { Ellard, Sian; University of Exeter Medical School, Institute of Biomedical } \\
\text { and Clinical Science } \\
\text { Han, Bing; University of Manchester, Faculty of Biology, Medicine and } \\
\text { Health } \\
\text { Mohamed, Zainab; Royal Manchester Children's Hospital, Paediatric } \\
\text { Endocrinology; University of Manchester, Faculty of Biology, Medicine and } \\
\text { Health } \\
\text { Dunne, Mark; University of Manchester, Faculty of Biology, Medicine and } \\
\text { Health } \\
\text { Bitetti, Stefania; St Mary's Hospital, Paediatric Histopathology }\end{array}$ \\
\hline Keywords: & $\begin{array}{l}\text { hypoglycaemia, sudden infant death, post-mortem, congenital } \\
\text { hyperinsulinism, pancreas, insulin }\end{array}$ \\
\hline Abstract: & $\begin{array}{l}\text { Congenital hyperinsulinism (CHI) is the commonest cause of persistent and } \\
\text { severe hypoglycaemia in infancy due to unregulated insulin secretion from } \\
\text { pancreatic beta cells. Prompt early diagnosis is important, as insulin } \\
\text { reduces glucose supply to the brain, resulting in significant brain injury and } \\
\text { risk of death. Histologically, } \mathrm{CHI} \text { has focal and diffuse forms; in focal CHI, } \\
\text { an inappropriate level of is secreted from localised beta-cell } \\
\text { hyperplasia. We report a four-month old boy, who presented with sudden } \\
\text { illness and collapse without a recognised cause and died. Post-mortem } \\
\text { examination revealed pancreatic histopathology compatible with focal } \\
\mathrm{CHI} \text {. Immunofluoresence-staining showed limited expression of p57kip2 } \\
\text { beta-cells reinforcing the diagnosis. Mutation testing for genes associated } \\
\text { with CHI from DNA from the focal lesion was negative. This case highlights } \\
\text { the recognition of focal CHI as a possible cause for sudden infant death. In } \\
\text { children dying suddenly and unexpectedly, post-mortem pancreatic } \\
\text { sections should be carefully examined for focal CHI. }\end{array}$ \\
\hline
\end{tabular}




\title{
Pediatric and Developmental Pathology
}

\section{Case Report}

Title: Focal Congenital Hyperinsulinism as a cause for Sudden Infant Death

\begin{abstract}
Authors: Dr Amish Chinoy ${ }^{1}$ (amishchinoy@doctors.org.uk), Dr Indraneel Banerjee ${ }^{1}$ (indi.banerjee@cmft.nhs.uk),Dr Sarah E Flanagan² (‥flanagan@exeter.ac.uk), Professor Sian Ellard² (‥ellard@exeter.ac.uk), Bing Han ${ }^{3}$ (bing.han-3@postgrad.manchester.ac.uk), Dr Zainab Mohamed ${ }^{1,3}$

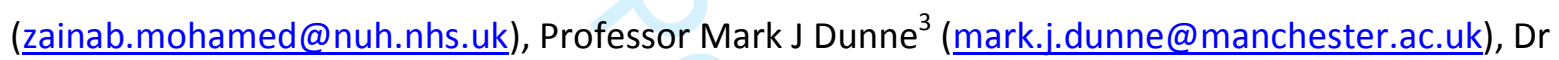
Stefania Bitetti ${ }^{4}$ (stefania.bitetti@cmft.nhs.uk)
\end{abstract}

Institutions:

1. Department of Paediatric Endocrinology, Royal Manchester Children's Hospital, Manchester, UK 2. Institute of Biomedical and Clinical Science, University of Exeter Medical School, Exeter, UK 3. Faculty of Biology, Medicine \& Health, University of Manchester, Manchester, UK 4. Department of Paediatric Histopathology, St Mary's Hospital, Manchester, UK Corresponding author: Dr Stefania Bitetti; stefania.bitetti@cmft.nhs.uk; Department of Paediatric Histopathology, St Mary's Hospital, Oxford Road, Manchester, UK, M13 9WL; 004401617211269

Running head: Focal $\mathrm{CHI}$ and Sudden Infant Death 
Grant support: The authors received support from the NORCHI Charitable Fund (M.J.D, I.B.) , The National Institute for Health Research (M.J.D., I.B.), the Million Dollar Bike Fund (Pilot Award Number: MDBR-16-100-CHI; M.J.D.,I.B.) and the Sir Henry Dale Fellowship jointly funded by the Wellcome Trust and the Royal Society (Grant Number: 105636/Z/14/Z; SEF)

Acknowledgements: None

Declarations of Conflicts of Interest: The Authors declare that there is no conflict of interest Focal Congenital Hyperinsulinism as a cause for Sudden Infant Death

\begin{abstract}
Congenital hyperinsulinism ( $\mathrm{CHI})$ is the commonest cause of persistent and severe hypoglycaemia in infancy due to unregulated insulin secretion from pancreatic beta cells. Prompt early diagnosis is important, as insulin reduces glucose supply to the brain, resulting in significant brain injury and risk of death. Histologically, $\mathrm{CHI}$ has focal and diffuse forms; in focal $\mathrm{CHI}$, an inappropriate level of is secreted from localised beta-cell hyperplasia. We report a four-month old boy, who presented with sudden illness and collapse without a recognised cause and died. Post-mortem examination revealed pancreatic histopathology compatible with focal $\mathrm{CHI}$. Immunofluoresence-staining showed limited expression of $\mathrm{p} 57^{\mathrm{kip} 2}$ beta-cells reinforcing the diagnosis. Mutation testing for
\end{abstract}


genes associated with $\mathrm{CHI}$ from DNA from the focal lesion was negative. This case highlights the recognition of focal $\mathrm{CHI}$ as a possible cause for sudden infant death. In children dying suddenly and unexpectedly, post-mortem pancreatic sections should be carefully examined for focal $\mathrm{CHI}$.

Key words: congenital hyperinsulinism, hypoglycaemia, post-mortem, sudden infant death, pancreas, insulin

Running head: Focal $\mathrm{CHI}$ and Sudden Infant Death

\section{Introduction}

Congenital hyperinsulinism $(\mathrm{CHI})$ is the commonest cause of persistent and severe hypoglycaemia in infancy. $\mathrm{CHI}$ typically presents in the neonatal period, although cases in infancy and even childhood have been reported [1]. These infants typically present with symptoms of hypoglycaemia, with detectable/inappropriate insulin and C-peptide levels for hypoglycaemia, along with suppressed beta-hydroxybutyrate and free fatty acids. Prompt diagnosis is important, as the presence of insulin inhibits ketone formation, resulting in significant brain injury if the hypoglycaemia is persistent or profound [2]. Acute management involves provision of high concentration glucose, either in feeds or parenterally, and glucagon as an emergency measure. Long-term medical management includes diazoxide and octreotide as first-line and second-line options respectively. Failing response to medical therapy, pancreatectomy may be required [3]. 
$\mathrm{CHI}$ refers to a heterogenous group of conditions, with genetic aetiology in around $40 \%$ of patients with mutations in 11 known genes, those affecting the ATP sensitive $\mathrm{K}^{+}$-channel $(A B C C 8 / K C N J 11)$ being most frequent $[4,5]$. Histologically, $\mathrm{CHI}$ can be classified broadly into focal and diffuse forms. In the diffuse form, hyper-functioning pancreatic beta cells with nucleomegaly are distributed throughout the pancreas, whereas in the focal form there is nodular hyperplasia of islet cells surrounded by normal tissue [6].

We report a four-month old male infant who died in hospital after presentation with an acute illness and collapse. Pancreas histology at post mortem revealed an isolated focal lesion in keeping with focal $\mathrm{CHI}$.

\section{Case Report}

A four-month old boy presented to hospital unresponsive.

The background to this episode was birth at $34+4$ weeks of gestation following normal vaginal delivery, with a weight of $1.84 \mathrm{~kg}\left(9^{\text {th }}\right.$ centile) and satisfactory Apgar scores ( 8 at 1 minute and 9 at 5 minutes). He spent 10 days on the neonatal unit, requiring antibiotics for suspected sepsis. He had received phototherapy for unconjugated hyperbilirubinaemia. Hypoglycaemia was identified by point of care testing during this neonatal period on more than one episode and was promptly treated with frequent feeds, although a venous sample for confirmation was not obtained and the specific value of glucose was not recorded in the case notes. The cause for hypoglycaemia at the time was not investigated. Hypoglycaemia was corrected for inadequate glucose intake on the 
background of prematurity, as per the unit policy. Sepsis was presumed to be a cause for hypoglycaemia and treated robustly, although blood cultures were negative indicating that infection was an unlikely aetiology. Following discharge from the neonatal unit, he had reportedly been well until just prior to representation.

Prior to representation, the parents had noted blood in his nappy. Balanitis was diagnosed, and treated with oral antibiotics in the community. The following day he fed poorly, and suffered from vomiting and diarrhoea. His condition deteriorated rapidly and he became unresponsive. He was rushed to hospital, where he was noted to be hypothermic, pale, with circulatory failure. There were no external signs of bleeding. Initial blood tests showed profound hypoglycaemia (serum glucose $<1.0 \mathrm{mmol} / \mathrm{L}$ ), acidosis ( $\mathrm{pH} 6.96$ ) and pancytopaenia (haemoglobin $56 \mathrm{~g} / \mathrm{L}$, white cell count $1.6 \times 10^{9} / \mathrm{L}$, platelet count $\left.49 \times 10^{9} / \mathrm{L}\right)$. Despite extensive resuscitative measures, including ventilatory support, fluid boluses, inotropes and antibiotics, he died within 4 hours of presentation.

A Coroner's post-mortem examination was conducted. Autopsy revealed a male infant with normal growth, with crown heel length $(59 \mathrm{~cm})$ and weight $(6.08 \mathrm{~kg})$ between 50 th and 75 th centiles for his corrected age for gestation ( 2 months and 3 weeks). No congenital abnormalities of the internal organs were identified at autopsy. A male karyotype was noted in keeping with male genitalia. Post mortem examination did not identify liver or kidney tumours; there were no clinical features of Beckwith Wiedemann syndrome. A widespread petechial rash was present. Bone marrow histology showed a severely left shifted marrow with immature precursor cellular profile, thus raising the possibility of sepsis/acute infective terminal illness. However, no positive bacterial culture or tissue inflammation was ever identified. 
The most significant finding was found on pancreas histology. This revealed a localised (focal) expansion of islets interspersed within normal pancreatic tissue suggestive of focal CHI. Targeted next generation sequencing of DNA isolated from pancreatic tissue did not reveal any coding mutations or changes in the copy number of the ATP sensitive $\mathrm{K}^{+}$channel genes, $A B C C 8$ and KCNJ11. Coding mutations and partial/whole gene in GLUD1, GCK, HADH, HNF4A, HNF1A, INSR and TRMT10A were also excluded. Immunohistochemistry and immunofluorescence studies were performed on $5 \mu \mathrm{m}$-thick sequentially sectioned tissue slides (heat-mediated antigen retrieved) as previously described $[6,7]$. Insulin (Abcam 1:1000 rabbit), glucagon (RTU Biogenex PA039-5PSG) and somatostatin (Dako 1:2000 A00566) staining were performed to examine islet cell expression. All slides were digitised as previously described [6,7]. Figure $1 \mathrm{~A}$ illustrates the histological characteristics of the pancreas, with the focal domain associated with islet cell hyperplasia, in contrast to the non-focal region. Figure 1B demonstrates the immunological characteristics - how the focal lesion is associated with a marked expansion of insulin-expressing islet cells and the location of glucagon-expressing cells within the lesion. Glucagon expression is localized to the peripheral regions of the focal islets. Figure 2 shows the expression and localization of islet insulin, glucagon and somatostatin within the lesion and the non-lesion domains of the pancreas. Note the expansion of insulin-positive cells within the lesion and how the non- $\beta$-cells are located around the periphery of the islet and islet-like structures. To address the mechanism of islet $\beta$-cells expansion we assessed the expression of $p 57^{\mathrm{kip} 2}$ by immunohistochemistry (1:50, mouse; Thermo Scientific, UK), also demonstrated in Figure 2. $\mathrm{P} 57^{\mathrm{kip} 2}$ is normally expressed in $\beta$-cell nuclei where it acts as a negative repressor of the cell cycle. Focal $\mathrm{CHI}$ is caused by the loss of heterozygosity on Ch.11p15 and loss of $\mathrm{p} 57^{\mathrm{kip} 2}$ expression. This was confirmed in tissue samples from the lesion domain. 
On the balance of probabilities the cause of death was felt to be related to the focal lesion in the pancreas most probably resulting in hypoglycaemia.

\section{Discussion}

We have reported focal $\mathrm{CHI}$ as a probable cause of death in a child with infantile hypoglycaemia, presenting with sudden illness and collapse. Focal $\mathrm{CHI}$ is well recognised as a cause for early and late presenting hypoglycaemia [8]. While neonatal hypoglycaemia is detected early when the child is still in hospital, infantile hypoglycaemia due to late presenting $\mathrm{CHI}$ can be missed and the diagnosis therefore delayed. We have highlighted in our case report an extreme scenario where focal $\mathrm{CHI}$ was not diagnosed until after post-mortem examination.

The incidence of focal $\mathrm{CHI}$ as a cause of sudden unexpected infant death has not been reported. It is important to raise awareness that focal $\mathrm{CHI}$ may cause hypoglycaemia severe enough to cause death from delayed recognition. For histopathologists, it is important to consider the possibility of focal $\mathrm{CHI}$ when examining pancreatic sections in post-mortem examinations.

It was not possible to establish the diagnosis of $\mathrm{CHI}$ in the neonatal period as samples for serum insulin had not been drawn at the time of hypoglycaemia. Further, samples for glucose and insulin were not analysed in the post-mortem period as measurements several hours after death would be too unreliable. However, the diagnosis of focal $\mathrm{CHI}$ in our case was comprehensively confirmed by standard examination of pancreatic sections, followed by immunofluorescence staining for insulin and $\mathrm{p} 57^{\mathrm{kip2}}$. Although a genetic aetiology was not ascertained, the diagnosis of focal $\mathrm{CHI}$ was unequivocal. 
In most cases of focal $\mathrm{CHI}$, diagnosis is made following the identification of paternal heterozygous mutations in $A B C C 8 / K C N J 11$ in peripheral blood DNA and confirmation by 18 -fluoro-dopa PET-CT scanning [9]. In the presented case, a diagnosis of $\mathrm{CHI}$ was not suspected at any stage of life and the above investigations of gene mutation testing and imaging were not undertaken. Focal $\mathrm{CHI}$ was identified only at post-mortem on histology.

\section{Conclusions}

This case demonstrates the consequences and severity of focal $\mathrm{CHI}$; if not recognised, investigated and treated, focal $\mathrm{CHI}$ can lead to death. This case also highlights the need for careful assessment of the pancreas in post-mortem examination in children dying suddenly and unexpectedly.

\section{References $(\max 15)$}

1. Arnoux JB, Verkarre V, Saint-Martin C, et al. Congenital hyperinsulinsm: current trends in diagnosis and therapy. Orphanet J Rare Dis. 2011;6(63):1-14.

2. Avatapalle HB, Banerjee I, Shah S, et al. Abnormal neurodevelopmental outcomes are common in children with transient congenital hyperinsulinsm. Front Endocrinol. 2013;4(60):1-6.

3. Roženková K, Gúemes M, Shah P, Hussain K. The diagnosis and management of hyperinsulinaemic hypoglycaemia. J Clin Res Pediatr Endocrinol. 2015;7(2):86-97.

4. Stanley CA. Perspective on the genetics and diagnosis of congenital hyperinsulinsm disorders. J Clin Endocrinol Metab. 2016;101(3):815-826. 
5. Flanagan SE, Kapoor RR, Hussain K. Genetics of congenital hyperinsulinaemic hypoglycaemia. Semin Pediatr Surg. 2011;20(1):13-17.

6. Han B, Newbould M, Batra G, et al. Enhanced islet cell nucleomegaly defines diffuse congenital hyperinsulinism in infancy but not other forms of the disease. Am J Clin Pathol. 2016;145(6):757-68.

7. Salisbury RJ, Han B, Jennings RE et al. Altered Phenotype of $\beta$-Cells and Other Pancreatic Cell Lineages in Patients With Diffuse Congenital Hyperinsulinism in Infancy Caused by Mutations in the ATP-Sensitive K-Channel. Diabetes. 2015;64(9):3182-8.

8. Banerjee I, Skae M, Flanagan S et al. The contribution of rapid KATP channel gene mutation analysis to the clinical management of children with congenital hyperinsulinism. Eur J Endocrinol. 2011;164(5):733-40.

9. Banerjee I, Avatapalle B, Padidela R, et al. Integrating genetic and imaging investigations into the clinical management of congenital hyperinsulinism. Clinical Endocrinology 2013;78:803-813. 

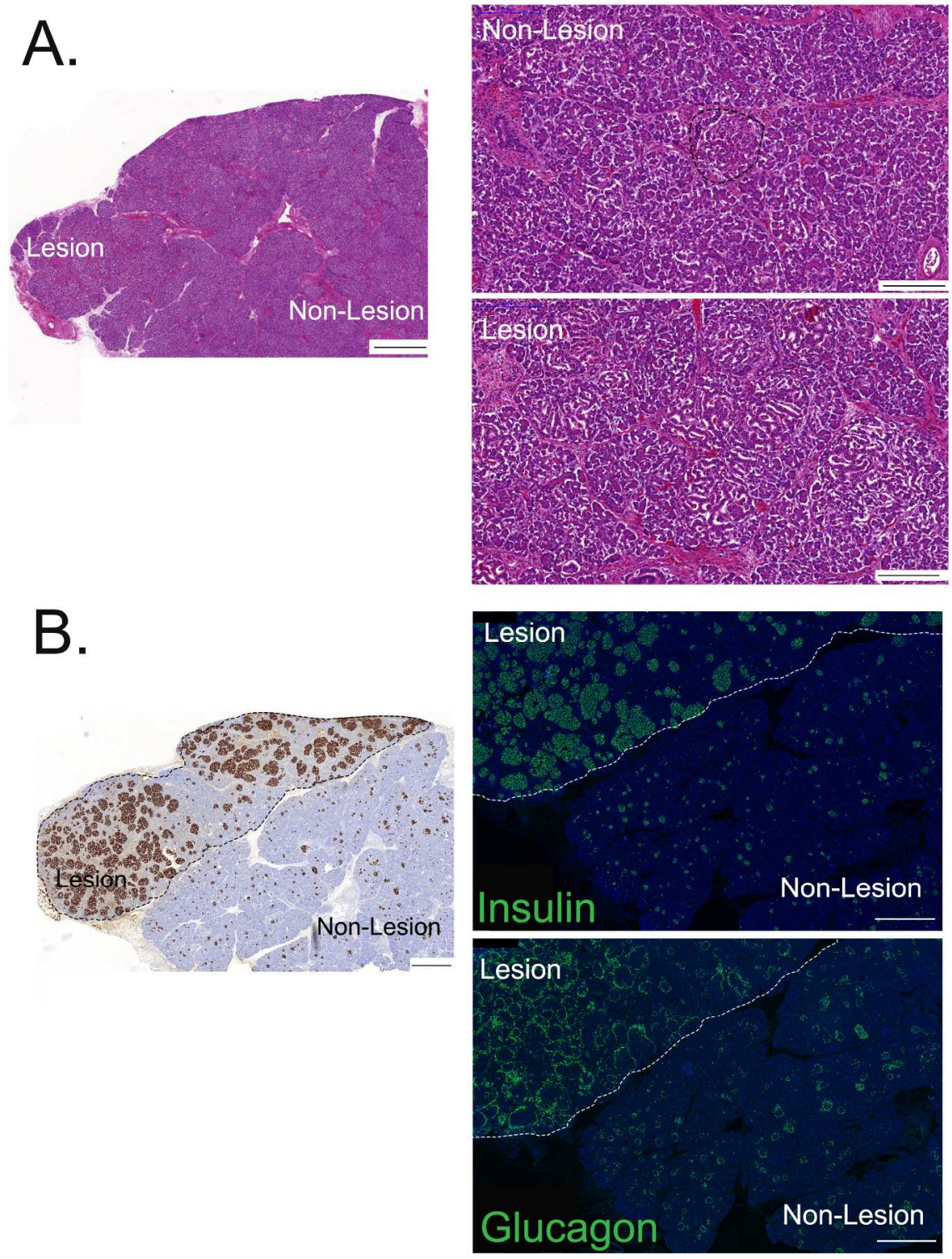

Figure 1. Histological and immunological characteristics of the pancreas. Panel A high and low power H\&E images of the pancreas. The focal domain 'Lesion' is associated with islet cell hyperplasia. In the non-focal region - 'Non-Lesion', islets can be readily observed, indicated by dotted region. Panel B illustrates the expression of insulin by immunohistochemistry in the tissue block. Note the enrichment of insulin-expressing cells in the designated lesion domain compared to the expression of insulin in the remainder of the pancreas, Panel A low power image (x5), scale bar 1mm; high power images (x40), scale bars 200 $\mu \mathrm{m}$. Panel B magnification $2.5 \mathrm{X}$, scale bars $1 \mathrm{~mm}$. 

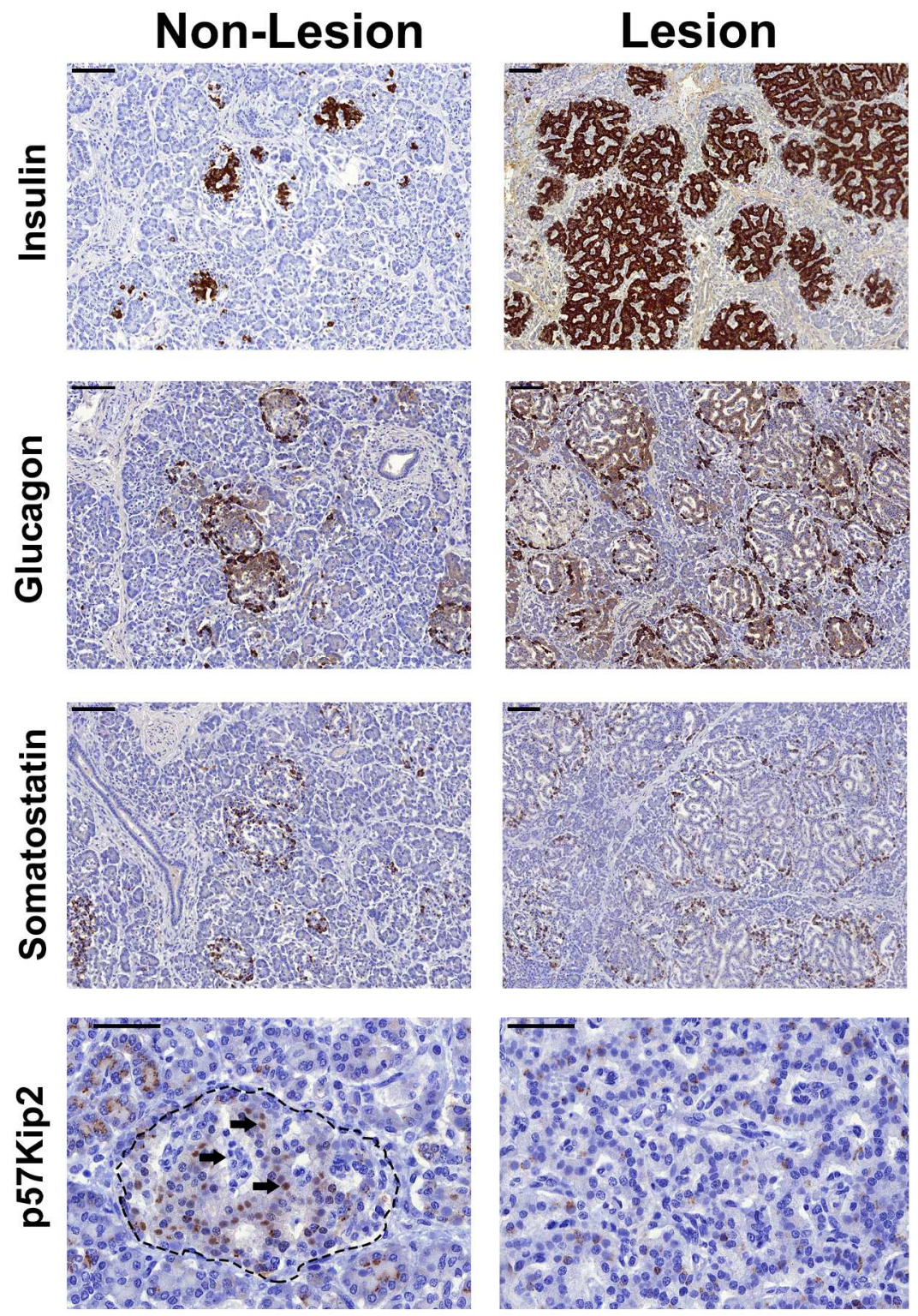

Figure 2. Islet hormone expression in the focal and non-focal domains of the $\mathrm{CHI}$ pancreas. In the nonlesion domains of the tissue insulin expression is largely found within islet structures with a central location within the islet domain. Glucagon and somatostatin expression is localized to the periphery of the islets. The focal lesion is characterized by extensive expression of insulin-positive cells, with glucagon- and somatostatin-expressing cells around the peripheral structures of the extended structures. Islets outside of the focal lesion have nuclei localization of p57kip2, whereas islet cells within the lesion do not express p57kip2. Images 20-40X magnification; Scale bars: $100 \mu \mathrm{m}$ for all images, except p57kip2; $50 \mu \mathrm{m}$. 